\title{
ЗАКОНОДАВЧЕ ЗАБЕЗПЕЧЕННЯ ОСВІТИ ДОРОСЛИХ В УКРАЇНІ: СУЧАСНИЙ СТАН ТА ПЕРСПЕКТИВИ РОЗВИТКУ
}

\author{
Наукова співдоповідь на загальних зборах НАПН України 20 листопада 2020 р.
} https://doi.org/10.37472/2707-305X-2020-2-2-1-2

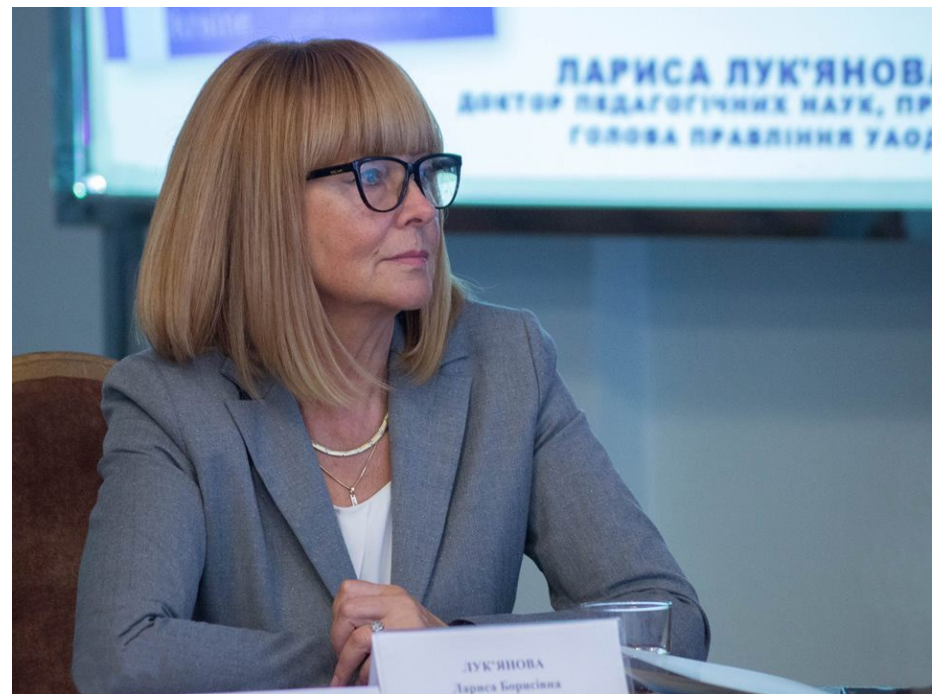

\section{ЛУК'ЯНОВА Лариса Борисівна}

доктор педагогічних наук, професор, член-кореспондент НАПН України, директор Інституту педагогічної освіти і освіти дорослих імені Івана Зязюна Національної академії педагогічних наук України, м. Київ, Україна

Анотація. Схарактеризовано чинники, що обумовлюють зростання ролі освіти дорослих на початку XXI cm., з поміж-яких найбільш вагомими автор визначає розвиток науково-технічного прогресу, зміни у змісті й характері праці, збільшення вільного часу та розширення спектру можливостей його використання. Представлено аналіз інформачії Євростату щодо участі дорослого населення країн ЄС в освіті і навчанні, а також міжнародних звітів з навчання впродовж життя, які свідчать, що за останні десять років у країнах EC спостерігалося збільшення участі дорослого населення в освіті і навчанні; особливо помітне зростання спостерігається у неформальній освіті; у звітах також зафіксовано наявність позитивного впливу різних форм освіти і навчання дорослих на продуктивність праці та зайнятість.

Автор обгрунтовує, що одним із показників розвитку системи освіти дорослих єії нормативно-правове забезпечення, рівень якого у переважній більшості зарубіжних країн є достатньо високим. Висвітлено зміни, що відбулися у розвитку законодавчого забезпечення України. Проаналізовано зміст проєкту закону України «Про освіту дорослих» (його ініціатори й співавтори МОН України, Українська асоціація освіти дорослих, Інститут педагогічної освіти і освіти дорослих імені Івана Зязюна НАПН України), який пройшов громадське обговорення і готується на погодження до заінтересованих органів виконавчої влади. Схарактеризовано зміст розділів і статей, за якими унормовують питання, що раніше не підпадали у законодавче поле (статус і основні принципи діяльності Національної ради з питань підтримки освіти дорослих; створення Фонду підтримки освіти дорослих, визнання результатів навчання, здобутих у несормальній освіті; провайдери освіти дорослих; підготовка педагогічного персоналу для системи освіти дорослих). Розкрито проблеми, вирішення яких сприятиме розвитку наукового забезпечення освіти дорослих в Україні, загалом та його нормативно-правового забезпечення зокрема.

Ключові слова: освіта дорослих; нормативно-правове забезпечення; статті закону; підвищення кваліфікації.

Зростання ролі освіти дорослих на початку XXI ст. зумовлюється динамікою соціального і науковотехнічного прогресу, змінами у змісті й характері праці, збільшенням вільного часу та можливостями його раціонального використання. Освіта дорослих стає ключовим компонентом цілісної загальної системи освіти і навчання впродовж життя.

На думку економістів, важливим показником розвитку системи освіти дорослих є участь дорослого населення в освіті і навчанні. Інформація 
Євростату свідчить, що впродовж останніх десяти років у країнах ЄС спостерігалося як зростання, так і незначне зменшення участі. У 2019 р. частка дорослих в країнах ЄС у віці від 25 до 64 рр., які брали участь у навчанні, становила 10,8 \%, що на 0,7 \% перевищує відповідні показники 2014 р. У цьому ж році Данія, Фінляндія та Швеція зазначили про збільшення кількості дорослого населення, яке брало участь у навчанні впродовж життя і становило від 25,3 \% до 34,3 \%.

Результати міжнародних експертних опитувань свідчать про наявність позитивного впливу різних форм освіти і навчання дорослих на продуктивність праці та зайнятість. Так, у Третьому глобальному звіті ЮНЕСКО з навчання впродовж життя («Third Global Report on Adult Learning and Education», 2016) зазначено, що 49 \% респондентів з різних країн наголошують на важливості професійної освіти і навчання, $45 \%$ - на значенні неформальної освіти на робочому місці, 43 \% на актуальності вищої професійної освіти та корпоративного навчання, $41 \%$ - на доцільності самостійного навчання.

Рівень участі дорослого населення у неформальній освіті постійно зростає, про що свідчать ії провідні позиції у системах освіти впродовж життя. Так, згідно зі звітом «Education at a Glance» (2016) рівень участі у неформальній освіті громадян країн-членів OECD віком 25-64 років коливається від $17 \%$ у Туреччині до 64 \% у Новій Зеландії. Цей показник є вищим у порівнянні з Данією, Швецією, Фінляндією, які традиційно посідали перші місця. Середній показник серед 30 країн, які брали участь в опитуванні, є також достатньо високим і становить майже 50 \%.

Одним із показників розвитку системи освіти дорослих $\epsilon$ рівень ії нормативно-правового забезпечення. У більшості країн світу законодавство у сфері освіти дорослих $є$ розгалуженим й поєднує закони, засновані на цілісному й конкретизованому сприйнятті цієї освітньої сфери та закони, в яких освітня практика не є предметом законодавчого врегулювання.

Україна залишається однією з небагатьох європейських країн, яка не має цілісного законодавчого забезпечення освіти дорослих. Такий стан $\epsilon$ перепоною у розвитку освіти дорослих. Органи місцевого самоврядування не вкладають кошти у створення центрів або інших закладів освіти дорослих через неунормованість законодавчого забезпечення. Відсутність профільного закону нерідко є підставою для відмови казначейством у здійсненні відповідних виплат на освіту дорослих.

У Концепції розвитку освіти дорослих в Україні, розробленій нами у 2010 р., наголошено, що освіта дорослих має набути законодавчого унормування з визначенням принципів і механізмів державної підтримки, ролі основних суб'єктів, їх прав і обов'язків, способів координації між різними провайдерами освітніх послуг, а також механізмів фінансування з бюджету. Для цього потрібно прийняти Закон України «Про освіту дорослих» та відповідні підзаконні акти, розвивати освіту дорослих як цілісну систему, що уможливлює гарантії і права кожного громадянина країни на безперервну освіту впродовж життя, спрямовану на загальнолюдські цінності, ідеали гуманізму.

Останнім часом Україна здійснила важливі кроки у напрямі законодавчого забезпечення освіти дорослих. По-перше, до Закону України «Про освіту» (від 5 вересня 2017 р.) було включено статтю 18 «Освіта дорослих» і, по-друге, було прийнято рішення про необхідність підготовки окремого Закону України «Про освіту дорослих». У Міністерстві освіти і науки України було створено робочу групу, до складу якої увійшли вчені структурних підрозділів НАПН України.

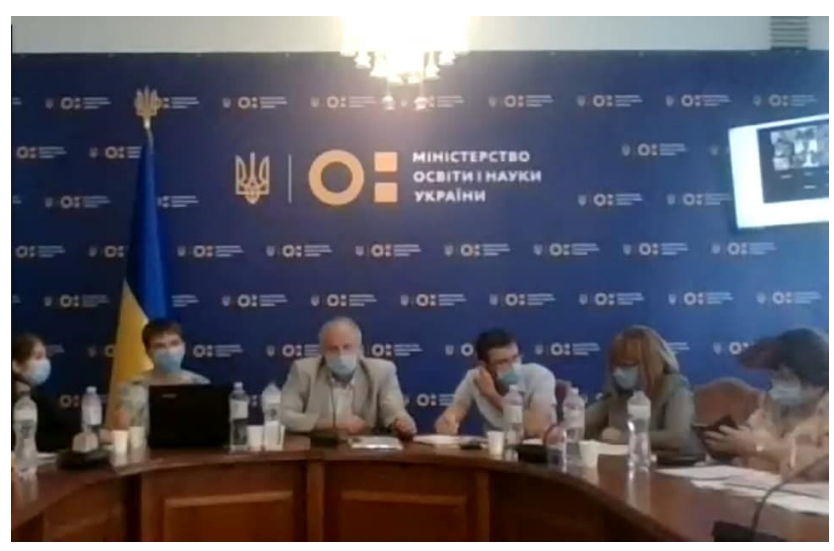

У вересні цього року Міністерством освіти і науки України на громадське обговорення було винесено проєкт Закону України «Про освіту дорослих», ініціаторами й співавторами якого стали МОН України, Українська асоціація освіти дорослих та Інститут педагогічної освіти і освіти дорослих імені Івана Зязюна НАПН України (МОН України, 2020). Наразі відбувається доопрацювання законопроєкту відповідно до зауважень і пропозицій, що надійшли під час його обговорення, та здійснюється підготовка до його направлення на погодження до заінтересованих органів виконавчої влади. 
Мета цього Закону - становлення основних правових організаційних, фінансових засад функціонування освіти дорослих в Україні, створення умов для ефективної співпраці здобувачів освіти, органів державної влади та місцевого самоврядування, інститутів громадянського суспільства, суб'єктів освітньої діяльності, роботодавців, інших зацікавлених сторін з метою забезпечення права дорослої особи на освіту впродовж житя, розвитку iï особистісних, громадянських та професійних компетентностей відповідно до індивідуальних потреб, потреб суспільства, економіки і держави.

Структура законопроєкту складається із 31 статті, об'єднаних у 7 розділів.

Цей законопроєкт відрізняється від попередніх включенням до його структури нових розділів і статей, за якими унормовують питання, що раніше не підпадали у законодавче поле.

Так, статтею «Статистика та дослідження в сфері освіти дорослих» передбачено встановлення державної статистичної звітності, збору статистичної інформації за результатами моніторингових досліджень якості освіти дорослих; статистичних показників, що відображають стан системи освіти дорослих. Юридичні особи, які займаються освітою дорослих, незалежно від форм власності будуть зобов'язані надавати статистичну звітність, а Державна служба статистики України забезпечуватиме оприлюднення статистичних даних щодо стану формальної і неформальної освіти дорослих у відкритих джерелах. Важливість цієї статті Закону підтверджується такими фактами. Інститут ЮНЕСКО з навчання впродовж життя (Гамбург) проводить збір статистичної інформації для П'ятого глобального звіту про навчання і освіту дорослих. До попередніх чотирьох звітів Україна не надсилала статистичних даних саме через відсутність такої статистичної інформації. А до останнього звіту інформацію було подано не у повному обсязі саме через означені причини.

Принципово новою у законопроєкті $€$ і стаття «Статус та основні принципи діяльності Національної ради з питань підтримки освіти дорослих» як постійно діючого консультативно-дорадчого органу при центральному органі виконавчої влади у сфері освіти і науки. Рада формуватиметься в результаті конкурсного відбору з числа представників громадських об'єднань, провайдерів освіти дорослих, національних і зарубіжних наукових та експертних організацій. До завдань цієї ради віднесено: систематичне відстеження та аналіз потреб в освіті дорослих; узагальнення зарубіжного

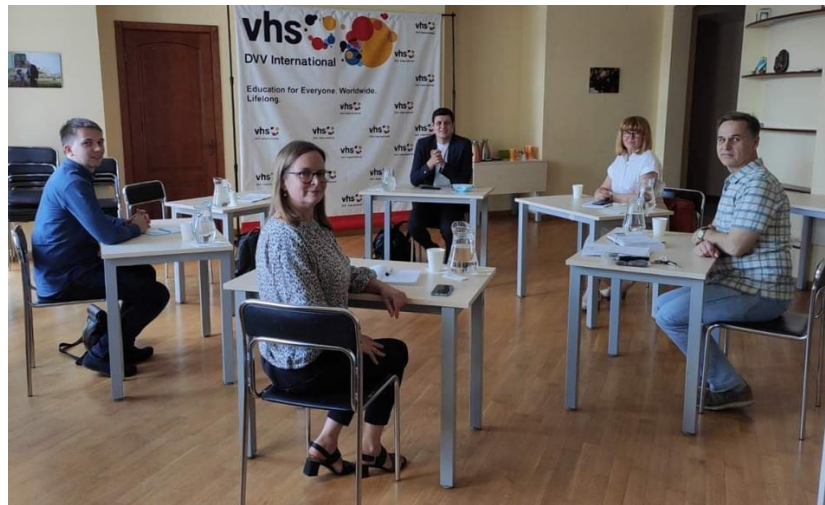

та вітчизняного досвіду у цій сфері; сприяння залученню представників інститутів громадянського суспільства, українських і міжнародних експертів до розвитку освіти дорослих; систематичне відстеження та аналіз освітніх потреб дорослих, а також розроблення методичних рекомендації для провайдерів щодо покращення якості наданих послуг. До повноважень Національної ради передбачається віднести питання щодо ухвалення державної стратегії розвитку освіти дорослих, оцінку стану ії виконання, аналіз якості освітньої діяльності провайдерів освіти дорослих тощо.

Нововведенням $\in$ і пропозиція щодо створення Фонду підтримки освіти дорослих, завдання якого полягатиме в сприянні реалізації проєктам у сфері освіти дорослих за пріоритетними напрямами, визначеними відповідно до Закону; наданні стипендій, грантів для навчання; підтримці інституційного розвитку провайдерів освіти дорослих.

у законопроєкті уперше передбачено врегулювання питання визнання результатів навчання, здобутих у неформальній освіті. Визнання ії результатів, сертифікація та акредитація - процес, всіляко підтримуваний міжнародними освітніми організаціями, багатьма країнами світу, що підтверджується прийнятими законами. Зокрема у Франції чинними є декілька законів, які унормовують механізми визнання результатів неформальної та інформальної освіти, а також сертифікації кваліфікацій, здобутих через досвід роботи. В інших країнах також накопичено відповідний досвід. У вітчизняному законопроєкті передбачено визнання результатів неформальної освіти, що охоплюватиме три етапи: ідентифікацію програми; оцінювання результатів навчання дорослої людини незалежними оцінювачами; видачу їй документа про визнання результатів навчання та / або присудження (присвоєння) часткової освітньої та / або професійної кваліфікації. 
У законопроєкті приділено увагу провайдерам освітніх послуг для дорослих. Залежно від засновника провайдер освіти дорослих може діяти як державний, комунальний, приватний заклад або установа. Такими установами є центри освіти дорослих та заклади освіти дорослих. Центр освіти дорослих - це провайдер або об'єднання провайдерів освіти дорослих - юридичних осіб, який (яке) надає освіту (освітні послуги) за більше, ніж однією освітньою програмою. Основним видом його діяльності є освітня діяльність у сфері освіти дорослих. Закладом освіти дорослих $є$ провайдер освіти дорослих, основним видом діяльності якого $€$ освіта дорослих у відповідній галузі, за відповідною спеціальністю (спеціальностями) та / або спеціалізацією (спеціалізаціями).

Нині помітно зростають потреби у андрагогах, отже, виникає необхідність визначення функціональних обов'язків фахівців, зайнятих у сфері освіти дорослих, серед них - викладачів закладів вищої освіти, закладів післядипломної освіти, консультантів, тьюторів, адміністраторів, управлінців, соціальних працівників, працівників корекційних установ і закладів.

Ці питання також відображено у змісті законопроєкту, де зазначено, що діяльність фахівцівандрагогів складається з навчання, консультування, надання соціальної допомоги та виконання організаційно-управлінських функцій в сфері освіти дорослих. До сфер його діяльності належать викладацька; науково-методична; культурнопросвітницька; дослідницька; управлінська.

Такий підхід має велике значення, оскільки наразі у професіоналізації освіти дорослих в Україні відбуваються позитивні зміни: в окремих університетах за ініціативою педагогів-ентузіастів викладаються різні курси з освіти дорослих, магістранти Національного педагогічного університету імені М.П.Драгоманова навчаються за спеціалізаціями «Андрагогіка» та «Тьюторство» (011 Освітні, педагогічні науки (Педагогіка вищої школи).

Вченими Інституту педагогічної освіти і освіти дорослих імені Івана Зязюна НАПН України було підготовлено обгрунтування та пакет документів, що дозволило у 2018 р. ввести до Державного класифікатора професію «Андрагог», та розроблено проєкт кваліфікаційної характеристики професії (посади) «Андрагог» для педагогічних і науково-педагогічних працівників закладів формальної і неформальної освіти. У цьому контексті важливою $є$ спільна з науковцями Університету мене- джменту освіти робота над створенням Професійного стандарту / стандарту професійної діяльності / готовності до професійної діяльності викладача системи освіти.

В умовах модернізації системи освіти України набуває особливого значення забезпечення доступу різних категорій дорослих до інформації про навчання упродовж життя, а також підвищення якості програм професійного розвитку.

У сучасних умовах викликом $є$ новий механізм підвищення кваліфікації, згідно з яким слухачі самостійно визначатимуть установу чи онлайнплатформу для розвитку професійних та особистісних компетентностей. Враховуючи те, що фахівці, які працюють з дорослими повинні мати високий рівень загальнонаукової компетентності та професійної підготовки, мають бути добре обізнаними з психології дорослих людей, теорії і технологій їх навчання та ін., у центрі підвищення кваліфікації, який працює на базі Інституту педагогічної освіти і освіти дорослих імені Івана Зязюна НАПН України, надаються консультації, проводяться заняття з формування андрагогічної компетентності. Серед слухачів курсів $€$ педагогічні працівники (у тому числі й директори шкіл), науковопедаго-гічні працівники (педагоги, юристи, культурологи, мистецтвознавці, музиканти) та інші фахівці.

У прикінцевих положеннях законопроєкту йдеться про необхідність внесення змін до Кодексу законів про працю, що передбачатимуть додаткову відпустку працівникам для навчання. Підготовлено також законопроєкти про внесення змін до Бюджетного та Податкового кодексів щодо забезпечення права дорослих осіб на освіту.

Отже, до проблем, вирішення яких сприятиме розвитку наукового забезпечення освіти дорослих в Україні, загалом та його нормативноправового забезпечення слід віднести такі:

Перше, сприяння у визнанні освіти дорослих невід'ємною складовою вітчизняної системи освіти й розроблення відповідного комплексу заходів щодо реалізації нормативного й правового регулювання.

Друге, важливим $€$ питання обґрунтування критеріїв потреб, планування, контролю, звітності, а також вивчення міжнародного досвіду наукового забезпечення освіти дорослих. Це зумовлює необхідність створення системи добору статистичної інформації з освіти дорослих на національному, регіональному й місцевому рівнях. 
Tpemє, створення державних центрів з підвищення кваліфікації й перепідготовки андрагогів (організаторів процесу навчання дорослих), що сприятиме підвищенню рівня компетентності спеціалістів, які працюють з дорослим населенням. До нагальних потреб доцільно віднести й створення факультетів і кафедр андрагогіки в усіх закладах вищої педагогічної освіти і в установах підвищення кваліфікації і перепідготовки працівників освіти.

Четверте, обґрунтування підходів щодо визнання і сертифікації формальної, неформальної та інформальної освіти дорослих, ключовим компонентом яких має стати система акредитації й оцінювання попереднього досвіду і знань особистості. Нагальною є підтримка пропозицій щодо освітніх послуг для різних категорій дорослого населення; розвитку механізмів інформаційного обміну; підвищення рівня професійної компетентності.

Отже, стратегічна ідея створення системи освіти дорослих в Україні та її наукового забезпечення набуває сукупного значення й загалом має впливати на державну політику як методологічний регулятор розвитку і окремої особистості, і держави загалом.

\section{СПИСОК ВИКОРИСТАНИХ ДЖЕРЕЛ}

Закон України «Про освіту». (2017, 5 вересня). https:// zakon.rada.gov.ua/laws/show/2145-19
Кремень, В.Г. (ред.). (2011). Національна доповідь про стан і перспективи розвитку освіти в Україні. Національна академія педагогічних наук України. Київ: Педагогічна думка. https://bit.ly/2VvrhOn

Кремень, В.Г. (ред.). (2016). Начіональна доповідь про стан і перспективи розвитку освіти в Україні. Національна академія педагогічних наук України. Київ: Педагогічна думка. https://lib.iitta.gov.ua/166230/

Лук'янова, Л.Б. (2011). Концепція розвитку освіти дорослих в Україні. Ніжин: ПП Лисенко М.М.

Лук'янова, Л. (2017). Законодавче забезпечення освіти дорослих: зарубіжний досвід. Київ: ТОВ «ДКСЦентр». https://bit.ly/37ArWn0

Лук'янова, Л.Б. (2018). Сучасні тенденції підготовки педагогічного персоналу для роботи з дорослими в європейських країнах. Андрагогічний вісник, (10), 7-17.

Міністерство освіти і науки України. (2020, 7 вересня). МОН пропонує для громадського обговорення проєкт Закону України «Про освіту дорослих». https://bit.ly/3lWykec

OECD. (2016). Education at a Glance. OECD Indicators. Paris: OECD Publishing. https://doi.org/10.1787/033aaa9den

UNESCO. (2016). 3rd Global Report on Adult Learning and Education: The Impact of Adult Learning and Education on Health and Well-Being; Employment and the Labour Market; and Social, Civic and Community Life. UNESCO Institute for Lifelong Learning. https:// uil.unesco.org/adult-education/global-report/thirdglobal-report-adult-learning-and-education-grale-3

UNESCO. (2019). 4th Global Report on Adult Learning and Education: leave no one behind: participation, equity and inclusion. UNESCO Institute for Lifelong Learning. https://uil.unesco.org/adult-education/global-report/ fourth-global-report-adult-learning-and-education

\title{
LEGISLATIVE REGULATION OF ADULT EDUCATION IN UKRAINE: CURRENT STATE AND PROSPECTS FOR DEVELOPMENT \\ Scientific co-report at the General Meeting of the National Academy of Educational Sciences of Ukraine, November 20, 2020
}

\author{
Larysa Lukianova \\ DSc in Pedagogy, Professor, Corresponding Member of NAES of Ukraine, Director, Ivan Ziaziun Institute of \\ Pedagogical and Adult Education of the National Academy of Educational Sciences of Ukraine, Kyiv, Ukraine
}

Abstract. The report states the key factors that have determined the growing role of adult education at the beginning of the XXI century, in particular the development of scientific and technological progress, changes in the content and nature of work, increased leisure time and expanded range of its use. The analysis of Eurostat data on EU adult participation in education and training, as well as international lifelong learning reports, revealed an increase of adults participation in education and training in the EU over the last ten years; a noticeable growth was observed in non-formal education; the figures indicate about a positive impact of various forms of adult education and training on productivity and employment.

The author substantiates that legislative support, which is at high level in most foreign countries, is among principal indicators of the adult education system development; the changes that have already taken place in the development of legislative support of Ukraine are highlighted. The content of the draft Law of Ukraine "On Adult Education" (initiated and cowritten by the Ministry of Education and Science of Ukraine, Ukrainian Association of Adult Education, Ivan Zyazyun Institute of Pedagogical and Adult Education of the National Academy of Educational Sciences of Ukraine) which was publicly discussed and is being prepared for approval by the relevant executive bodies, is analyzed; the sections and articles which regulate issues which haven't fallen under legislative field so far (status and basic principles of the National Council for Adult Education Support; creation of the Adult Education Support Fund, recognition of learning outcomes obtained in non-formal education; adult education providers; training of teaching staff for the adult education system). The solution of the problems revealed will contribute to the development of scientific support of adult education of Ukraine in general and its legal support in particular.

Keywords: adult education; Ukraine; legislative support; articles of the law; in-service training.

Дата публікації: 4 грудня 2020 р. 